\title{
Update of the recommendations for the determination of biomarkers in colorectal carcinoma: National Consensus of the Spanish Society of Medical Oncology and the Spanish Society of Pathology
}

\author{
P. García-Alfonso' (1) - R. García-Carbonero ${ }^{2} \cdot$ J. García-Foncillas $^{3} \cdot$ P. Pérez-Segura ${ }^{4} \cdot$ R. Salazar $^{5} \cdot$ R. Vera ${ }^{6}$. \\ S. Ramón y Cajal ${ }^{7} \cdot$ J. Hernández-Losa ${ }^{7} \cdot$ S. Landolf ${ }^{7} \cdot$ E. Musulén $^{8,9} \cdot$ M. Cuatrecasas $^{10} \cdot$ S. Navarro ${ }^{11}$
}

Received: 18 December 2019 / Accepted: 28 April 2020 / Published online: 16 May 2020

(c) The Author(s) 2020

\begin{abstract}
In this update of the consensus of the Spanish Society of Medical Oncology (Sociedad Española de Oncología MédicaSEOM) and the Spanish Society of Pathology (Sociedad Española de Anatomía Patológica-SEAP), advances in the analysis of biomarkers in advanced colorectal cancer (CRC) as well as susceptibility markers of hereditary CRC and molecular biomarkers of localized CRC are reviewed. Recently published information on the essential determination of KRAS, NRAS and $B R A F$ mutations and the convenience of determining the amplification of human epidermal growth factor receptor 2 (HER2), the expression of proteins in the DNA repair pathway and the study of $N T R K$ fusions are also evaluated. From the pathological point of view, the importance of analysing the tumour budding and poorly differentiated clusters, and its prognostic value in CRC is reviewed, as well as the impact of molecular lymph node analysis on lymph node staging in CRC. The incorporation of pan-genomic technologies, such as next-generation sequencing (NGS) and liquid biopsy in the clinical management of patients with CRC is also outlined. All these aspects are developed in this guide, which, like the previous one, will remain open to any necessary revision in the future.
\end{abstract}

Keywords Diagnosis · Neoplastic disease · Gastrointestinal · Genetic prognosis · Tumour

\section{Introduction}

During recent years, there have been advances related to the analysis of biomarkers with diagnostic, prognostic and therapeutic value in colorectal cancer (CRC), especially in advanced disease. Five years have passed since the last review of the consensus guide of the Spanish Society of Medical Oncology (Sociedad Española de Oncología Médica-SEOM) and the Spanish Society of Pathology (Sociedad Española de Anatomía Patológica-SEAP) [1], and it is important to update it to incorporate the advances that facilitate the administration of precision therapies to these patients.

In addition, this review examines the novelty of hereditary CRC susceptibility markers and the molecular biomarkers of localized CRC. Recently published information on the

P. García-Alfonso

pgarcaalfonso@gmail.com

Extended author information available on the last page of the article essential determination of KRAS, NRAS and BRAF mutations is also evaluated [2], as well as the convenience of determining other biomarkers, such as the amplification of the epidermal growth factor receptor (HER2), the expression of proteins in the DNA repair pathway and the study of NTRK fusions [2].

From a pathology point of view, new data have been published with a high degree of evidence regarding the diagnostic and prognostic value of some biomarkers that will be detailed in this review. One example is the incorporation into pathology diagnostic protocols the analysis of the tumour budding (TB), defined as the presence of isolated tumour cells or small groups of less than five tumour cells at the invasive tumour front, or the poorly differentiated clusters (PDC), defined as groups of five or more tumour cells at the invasive front of the stroma of the CRC which does not form glandular structures. Both, TB and PDC are prognostic factors in CRC [3, 4].

Another important pathological aspect is the introduction of new molecular assays for the analysis of lymph nodes extracted from surgical specimens of CRC. The 
pooling-OSNA ${ }^{\circledR}$ (one-step nucleic acid amplification) method, based on the RT-LAMP (reverse transcription loop-mediated isothermal amplification) of cytokeratin 19 (CK19) mRNA for the detection of lymph node metastases, surpassing the current performance of conventional morphological analysis with H\&E. Molecular lymph node staging is relevant, especially in the early stages of the disease [5].

Finally, this review evaluates the future incorporation of new pan-genomic technologies, such as next-generation sequencing (NGS) and liquid biopsy for the clinical management of patients with CRC. All these aspects are developed in this guide, which, like the previous one, will remain open to any necessary revision in the future.

\section{Clinical aspects}

\section{Molecular markers of hereditary CRC susceptibility}

Of all CRC cases diagnosed each year, $25 \%$ present some characteristic indicating hereditary cancer susceptibility. Of these, 5\% correspond to Lynch syndrome, $1 \%$ to polyposis and the rest to what could be called 'family aggregations'.
The identification of these clinical pictures has a high impact on the prevention of CRC, given that the identification of incipient neoplastic lesions leads to cure rates of up to $90 \%$ and affects comorbidities, quality of life and health efficiency.

\section{Lynch syndrome}

The identification of this type of syndrome is based on the Amsterdam I and II criteria [6, 7], which are exclusively clinical. When a family complies, genetic testing should be offered to identify the presence of germline mutations in DNA repair genes (mismatch repair $[M M R]$ genes), such as MLH1, MSH2, MSH6 and PMS2. This genetic study should always be accompanied by adequate genetic counselling.

The algorithm for the identification of these mutations is well described and accepted by different scientific societies (Fig. 1). Initial screening is performed by identifying the lack of expression of the corresponding proteins of the genes involved in CRC and/or endometrium or by analysing microsatellite instability [MSI]. Any of these techniques is fully accepted today, and each has its specificities. In the case that any of these alterations exist, and once it has been

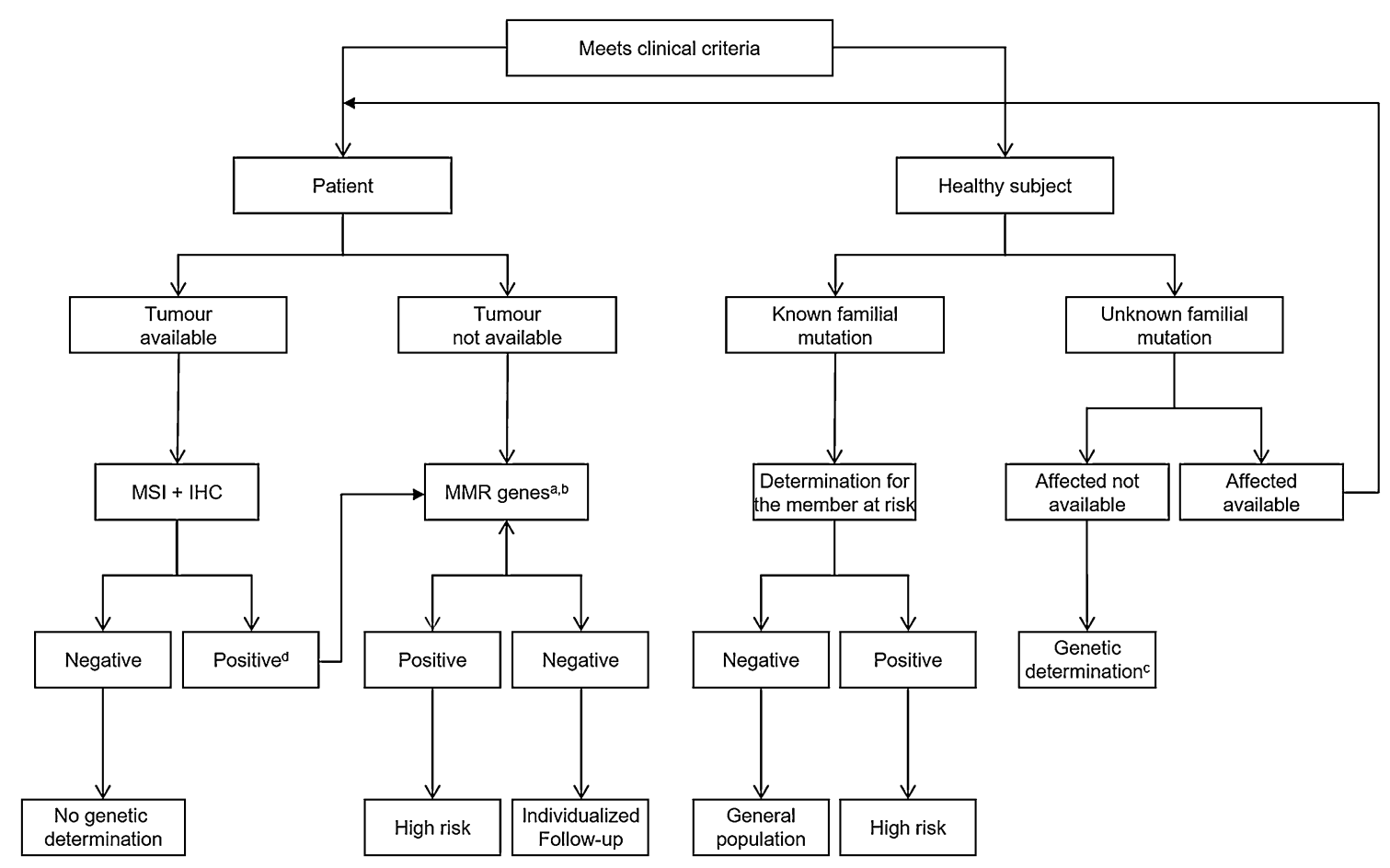

Fig. 1 Performance algorithm to detect Lynch syndrome. ${ }^{\text {aAssess }}$ at the individual level. ${ }^{\mathrm{b}}$ When there is no available tumour, but the Amsterdam criteria are met and the implications for the family are important, the option of conducting a study of germline mutations in $M M R$ genes should be evaluated. ${ }^{c}$ When there are no living or available affects, the germinal study should be evaluated in a healthy sub-

ject, as long as the impact on family management is important. ${ }^{\mathrm{d}}$ In the event that the lack of expression is in $M L H 1$, promoter methylation analysis and B6A6 V600E mutation should be performed. IHC immunohistochemistry, $M M R$ mismatch repair genes, MSI microsatellite instability 
ruled out that it is due to an exclusively somatic alteration, the germinal study of the $M M R$ genes should be performed.

Notably, at present, this type of study is being performed in any patient with CRC. This measure is justified not only by the preventive implications for the patient and their families but also because it helps to decide whether to administer adjuvant therapy in patients in whom the indication of such treatment is doubtful [8].

\section{Polyopsis syndromes}

The main characteristic of polyposis syndromes, which usually affect the younger population, is the development of a large number of polyps along the digestive tract, with different histologies and associated with other systemic lesions, with no histological markers to identify them.

If a person and/or their family have a polyposis syndrome, genetic counselling should be offered, and a germinal study of MMR genes should be carried out according to the clinical picture.

Taking into account this information, this panel of experts recommends the following:

- Perform MSI and/or immunohistochemistry (IHC) analysis for all patients diagnosed with CRC; and

- Continue with the germinal study of $M M R$ genes in patients in which MSI is observed and/or loss of expression of repair proteins, provided that an exclusively somatic origin has been ruled out.

\section{Molecular markers of localized CRC}

The use of adjuvant chemotherapy in patients with stage II $\mathrm{CRC}$ is controversial and is only recommended if at least one validated risk factor is observed. Among the clinical, pathological and molecular markers that have been correlated with progression-free survival (PFS) and overall survival (OS), only the evaluation of MSI versus stable microsatellites (MSs), T3 versus T4 and the number of lymph nodes analysed ( $\geq 12-14$ versus $<12-14$ ) have been validated repeatedly in prospective randomized clinical trials [9].

However, in patients with stage III CRC, the prognostic value of MSI is attenuated and is not observed in several large prospective cohort studies. The determination of alterations in $R A S$ and $B R A F$ has been shown to have prognostic value in recent randomized cohort studies but currently has no clinical utility [10].

Several multigenic tests have been developed with a commercial vision, but their overlap is low, and their clinical application is not guaranteed [11]. These tests have focused on patients with stage II CRC, in whom the evidence for administering adjuvant chemotherapy is conflictive, with the aim of selecting patients with higher risk and, therefore, who may benefit more from chemotherapy. Only two tests, Oncotype $\mathrm{DX}^{\circledR}$ and GeneFx ${ }^{\circledR}$ Colon [12], have been validated in cohorts of prospective and randomized patients by multivariate analysis in formalin-fixed paraffin-embedded (FFPE) tumour samples. Oncotype DX ${ }^{\circledR}$ is the genetic test with the most evidence and has been developed as a real-time polymerase chain reaction (RT-PCR) multigenic quantitative test. Its prognostic value has been observed in four independent prospective clinical trials that randomized patients with stage II CRC, observing hazard ratios (HR) between 1.43 and 1.68 [13-16]. It is important to note that Oncotype $\mathrm{DX}^{\circledR}$ maintains its prognostic value when other clinically relevant prognostic factors, such as T4 or MSI, are included in the multivariate analysis. However, its clinical utility is not guaranteed due to the lack of predictive value of the benefit of chemotherapy, as well as the small, but significant, prognostic differentiation between low, intermediate and high risk.

In this context, Immunoscore ${ }^{\circledR}$ has recently emerged as an alternative prognostic biomarker. It has been developed as a quantitative measure of the presence of $\mathrm{CD} 3+1$ CD8+ lymphocytes that have invaded a tumour. Both its internal validity and its external clinical validation have been demonstrated in long series of patients with stages II and III CRC through multivariate analysis, including when other factors, such as clinical stage and MSI status, were included in the multivariate analysis.[17]. However, the predictive value of the benefit of chemotherapy is uncertain and lacks independent evidence that demonstrates its prognostic value in stage II CRC, which is only observed when combined with known clinicopathological markers and MSI status.

More promising is the analysis of circulating tumour DNA (ctDNA), through which minimal residual disease can be detected with high prognostic value. If this is validated in the studies of clinical utility that are being carried out, these biomarkers may be the most robust in the near future [18]. Lastly, lack of CDX2 expression confers poor prognosis in stage 2 and may also predict benefit from adjuvant chemotherapy, but this must be confirmed in larger prospective randomized series [19].

\section{Essential molecular markers of advanced CRC}

CRC is a disease characterized by its high heterogeneity, a product of genomic instability and its interaction with multiple exogenous factors that influence carcinogenesis (diet, lifestyle, microbiome, etc.) and that constitutes the exposome. This genomic heterogeneity translates into different models of carcinogenesis and, ultimately, different phenotypes. Some of these genomic alterations can directly influence the selection of treatments; therefore, it is standard practice to determine the mutational state of multiple genes, including the determination of the extended $R A S$ mutation, 
the BRAF V600E mutation and the MSI status, which is usually performed by IHC staining for $M L H 1, M S H 2, M S H 6$ and $P M S 2$.

\section{RAS mutations}

The main biomarker of clinical utility in metastatic CRC is the mutational state of genes in the RAS family (KRAS/NRAS/HRAS). Mutations are present in approximately $50 \%$ of cases, the most frequent being those that occur in codons 12 and 13 of exon 2 and that condition a state of cellular expansion.

$R A S$ mutations are a predictor of the absence of response to treatment with epidermal growth factor receptor (EGFR) inhibitors, such as cetuximab and panitumumab. In the CRYSTAL study, the addition of cetuximab to the regimen with folinic acid, 5-fluorouracil and irinotecan (FOLFIRI) showed an increase in the response rate $(57 \%$ versus $40 \%$; $p<0.001)$ and median OS (23.5 versus 20.0 months; HR $0.796 ; p=0.0093$ ) in patients with tumours without $K R A S$ mutations [20]. However, in patients with tumours with KRAS mutations, a $4 \%$ decrease in the response rate was evidenced, and there were no significant differences in terms of OS [20]. Similar findings were found when analysing the OPUS trial, in which the chemotherapy regimen was folinic acid, 5-fluorouracil and oxaliplatin (FOLFOX) with cetuximab, and in the PRIME trial, in which FOLFOX was combined with panitumumab [21,22]. Taking into account these data [23], guidelines from the American Society of Clinical Oncology (ASCO), the European Society for Medical Oncology (ESMO) and the National Comprehensive Cancer Network (NCCN) recommend the extended determination of $R A S$ mutations before the administration of EGFR inhibitors [8, 24, 25]. The RAS analysis should include HRAS, KRAS and NRAS, exons 2 (codons 12 and 13), 3 (codons 59 and 61) and 4 (codons 117 and 146) [8, 24, 25].

\section{$B R A F$ mutations}

The most frequent $B R A F$ mutation is the substitution of glutamic acid for valine in codon V600E, which produces constitutive activation of the MAPK pathway. This mutation occurs in $8-10 \%$ of patients with metastatic CRC and excludes the RAS mutation [26]. It is more common in women, usually appears in more advanced stages and has been associated with tumours of the right colon, poorly differentiated, with mucinous histology and with MSI. Additionally, it seems that $B R A F$ mutations lead to the development of more peritoneal metastases and less disease limited to the liver or lung.

Regarding the prognostic role of $B R A F$, it seems that mutation is a negative prognostic factor, although its association with MSI has to be taken into account. A joint analysis of four phase III clinical trials of first-line treatment in patients with metastatic CRC evaluated the possible prognostic value of $B R A F$ [27]. In a total of 3063 patients, of whom $8.2 \%$ had a $B R A F$ mutation, the OS was 11.4 months, and the PFS was 6.2 months, compared to 17.2 months and 7.7 months, respectively, that were observed in patients without BRAF mutations $(p<0.001)$. This same study analysed the possible prognostic value of MSI, and it was observed that the OS for patients with MSI of high instability (MSI-H) was 13.6 months, while in patients with MSs, it was 16.8 months $(p=0.001)$. When the $B R A F$ and MSI statuses were analysed, there were no differences in terms of PFS or OS in the MSI-H population regardless of $B R A F$ status, but in the MSs population with mutated $B R A F$, a significant decrease in OS and PFS was observed. These data support the negative prognostic value of $B R A F$ mutations.

Recent data support the predictive value of $B R A F$ mutations [28]. Phase III BEACON Colorectal Cancer Study enrolled 665 patients with $B R A F \mathrm{~V} 600 \mathrm{E}$ across three cohorts, including the triplet regimen of encorafenib, binimetinib and cetuximab; the doublet regimen of encorafenib and cetuximab; and a control cohort where patients could receive either cetuximab and irinotecan or cetuximab with FOLFIRI. At the time of the interim analysis, the median duration of follow-up was 7.8 months. The median OS was 5.4 months, 8.4 months and 9.0 months for the control group, the doublet regimen arm, and the triplet regimen arm, respectively. Comparing the results obtained in the triplet regimen arm with the control group, HR was $0.52(p<0.001)$. An independent central review committee assessed the response rate in this analysis for the first 331 randomized patients. The response rate in the control arm was $2 \%$ compared with $20 \%$ in the doublet regimen arm and $26 \%$ in the triplet regimen arm (control arm versus triplet regimen arm; $p<0.001)$.

\section{MSI}

Mutations in the MLH1, MSH2, MSH6 and PMS2 genes are related to poor $M M R$ as well as MSI. They appear in $15 \%$ of stage II and III tumours but in only $4 \%$ of stage IV tumours. In stages II-III, MSI is related to a better prognosis, and specifically in stage II, the better prognosis occurs in the absence of benefits from adjuvant treatment with fluoropyrimidines. However, MSI in stage IV is associated with an unfavourable prognosis, most likely due to its association with $B R A F$ mutations.

Two recent studies show that the alteration of $M M R$ may have a predictive role in response to immunotherapy; therefore, the NCCN recommends its determination in all patients with metastatic CRC [29, 30]. The Food and Drug Administration (FDA) has approved the use of nivolumab 
and pembrolizumab in patients with $M M R$-deficient and MSI-H metastatic CRC.

\section{Recommended molecular markers of advanced CRC}

HER2 is overexpressed in a small proportion of CRC. The Cancer Genome Atlas (TCGA) project identified somatic amplifications or mutations of HER 2 in $7 \%$ of CRC cases and in 5\% of the non-hypermutated CRC subgroup (4\% amplification, $3 \%$ mutation and $1 \%$ both), being more frequent in native $R A S$ tumours (8\%) [31]. An analysis of 3256 patients with CRC from different clinical trials (QUASAR, FOCUS and PICCOLO) confirmed a higher incidence of HER2-positive CRC in native KRAS/BRAF tumours and advanced stages [32]. Some studies indicate that the amplification of HER2 is more frequent in distal tumours (PETACC- 3 and HERACLES-A), but others have not confirmed that observation (PETACC-8) [33]. Its association with survival is also controversial [32,33].

Protein overexpression and gene amplification are easily detectable by IHC or fluorescent in situ hybridization (FISH), respectively. The criteria developed and validated in the HERACLES programme defined HER2-positive tumours as tumours with an IHC staining intensity of $3+$ in more than $50 \%$ of cells or a staining intensity of $2+$ with a HER2:CEP ratio (chromosome enumeration probe) greater than 2 per FISH in more than 50\% of the cells [34]. Amplification of HER2 is involved in innate and acquired resistance to anti-EGFR drugs [33]. The dual inhibition of HER2 (lapatinib and trastuzumab or pertuzumab), but not the simple block, is capable of inducing durable responses in patientderived xenograft (PDX) models of native RAS/BRAF/PI3K cetuximab-resistant CRC [33]. Consistent with this, the HERACLES-A trial documented a response rate of $30 \%$ in 27 patients with native KRAS CRC, positive HER2, and anti-EGFR resistance treated with lapatinib and trastuzumab [35]. Similarly, in the MyPathway Phase II trial, a response rate of $38 \%$ was observed in 37 patients with HER2-positive metastatic CRC treated with trastuzumab and pertuzumab [36]. Other strategies being explored are anti-HER2 monoclonal antibody-drug conjugates, such as trastuzumabemtansine (HERACLES-B and RESCUE assays), and trastuzumab-deruxtecan, at a $25 \%$ response rate documented in a phase I study in 12 patients with HER2-positive CRC [37]. The determination of HER 2 may, therefore, be of clinical utility and could be justified at least in native $R A S$ tumours resistant to anti-EGFR treatment.

The constitutive activation of different kinases as a consequence of gene translocations plays an essential role in the tumourigenesis of multiple neoplasias, including a subgroup of neoplasias of the colon and rectum, and their pharmacological inhibition constitutes one of the greatest therapeutic successes in the field of precision oncology. In a recent series, in which 18,407 tumour samples and 513 ctDNA samples from CRC patients were characterized by massive sequencing, genetic rearrangements of potentially treatable kinases were identified in 126 tumours $(0.68 \%)$ and seven ctDNA samples (1.36\%) [38]. The most frequently identified fusions in this series involved the RET $(0.15 \%)$, BRAF (0.12\%), NTRK1 (0.14\%) and ALK (0.09\%) genes. Ninety percent of the tumours with these gene rearrangements were native $K R A S$, with a high proportion of MSI$\mathrm{H}: 86.4 \%, 45.5 \%$ and $14.3 \%$ of the tumours with NTRK1, $R E T$ and $A L K$ fusions, respectively. The presence of MSI or the absence of $R A S$ mutations may, therefore, help to better select the subgroup of patients in which it is more profitable to proceed to the molecular screening of these gene alterations.

These fusions can be identified with different methods. Classically, the detection of ALK or ROSI has been performed using FISH or RT-PCR, but there is a growing trend in the use of mass DNA sequencing techniques, which has the advantage of allowing the simultaneous evaluation of multiple genes with potential utility as therapeutic targets. Other useful techniques include complete or directed sequencing of tumour RNA, sequencing of circulating DNA or IHC (generally used as screening).

The presence of gene rearrangements in $A L K$, ROS1 or $N T R K$ has been associated with worse survival (15.6 versus 33.7 months for patients with $[n=27]$ or without [ $n=319]$ tumour gene fusions, respectively) [39]. RET fusions have also been associated with worse survival in a series of 24 positive RET patients [40]. In November 2018, the FDA approved the specific TRK inhibitor larotrectinib for the treatment of tumours with NTRK $1 / 2 / 3$ fusions, with an overall response rate of $75 \%$ (including two of three patients with CRC) and a median duration of response and PFS not attained after a median follow-up of 9.4 months (PFS at 1 year: 55\%) [39]. This is the second tumour-agnostic approval in the history of antineoplastic therapy after approval of pembrolizumab for MSI tumours. Entrectinib was approved in August 2019 for the treatment of tumours with NTRK fusions.

\section{Pathological aspects}

\section{What is relevant in the pathology diagnosis of CRC?}

\section{Tumour budding (TB) and poorly differentiated clusters (PDC)}

The most important prognostic factors in CRC according to the American Joint Committee on Cancer (AJCC) and the 8th edition of the International Union Against Cancer (UICC) are (i) TNM stage, (ii) venous, lymphatic or 
perineural invasion and (iii) discontinuous tumour deposits [41]. The determination of TB has been incorporated into the pathology diagnosis protocol of the College of American Pathologists (CRC) v4.0.0.1 and the NCCN guidelines v2.2019. Other factors, such as type, histological grade, the configuration of the tumour border and intratumoural inflammatory infiltrate, influence the prognosis and treatment of patients. Tumour budding or TB, defined by the presence of isolated tumour cells and/or groups of less than five cells in the stroma of an invasive front of the tumour, is the morphological evidence of the epithelial-mesenchymal transition process and is an independent factor of poor prognosis in CRC. TB is relevant in different clinical contexts: (i) in pT1 $\mathrm{CRC}$ as an independent predictor of lymph node metastasis, (ii) in stage II CRC predicts recurrence risk and contributes to therapeutic management $[42,43]$, and (iii) intratumoural TB in endoscopic biopsies allows the individualization of neoadjuvant treatment in rectal carcinomas $[44,45]$. The International Tumour Budding Consensus Conference (ITBCC) agreed to count TB with HE at the area of the tumour front with the most density using a $20 \times$ objective and a field of $0.785 \mathrm{~mm}^{2}$. TB is classified as Bd1-low (0-4 buds), Bd2-intermediate (5-9 buds) and Bd3-high (10 or more buds). Providing the numerical value of buds [e.g., $\mathrm{Bd} 3$ (count 17)] is recommended [46]. TB should be evaluated with caution in medullary carcinomas and can be very difficult to count in tumours with glandular fragmentation with marked acute inflammation. TB must be distinguished from PDCs, defined as groups of five or more tumour cells in the invasive tumour front that do not form glandular structures [4]. TB should not be reported in rectal tumours treated with neoadjuvancy, or in mucinous carcinomas with signet ring cells within mucus lakes. If TB cannot be assessed, it is indicated as no non-assessable with an explanatory note $[47,48]$.

\section{Lymph node staging}

Lymph node staging $(\mathrm{pN})$ is an important prognostic factor in CRC, a predictor of relapse and survival and determinant of the therapeutic management of patients. The $\mathrm{pN}$ stage is obtained from the analysis of lymph nodes stained with HE, which has low sensitivity for detecting lymph node micrometastases in stages I-II CRC. HE staining analyses less than $1 \%$ of lymph node tissue [49-53], resulting in 11-24\% false negatives. A meta-analysis concluded that the presence of micrometastases in lymph nodes undetected by HE is associated with worse survival [54]. To improve the sensitivity of lymph node analysis, molecular lymph node staging has been performed, which has shown an improvement in $\mathrm{pN}$ staging, with respect to HE.

The OSNA technique detects copies of CK19 messenger RNA (mRNA) in lymph nodes, achieving overstaging in $11-50 \%$ of HE-determined pN0 patients. Likewise, the total tumour load (TTL) or number of CK19 copies in the lymph nodes is correlated with classical high-risk factors in CRC, such as pT and pN stage, histologic grade, mucinous or signet ring histology, tumour size, male sex, lymphatic invasion and number of lymph nodes assessed [55, 56]. Recently, TTL has been correlated with prognosis. The incorporation of molecular lymph node staging in CRC will allow to select stage II patients for adjuvant therapy and assist patient management.

\section{What are the requirements of an optimal sample?}

For the study of biomarkers in CRC, a sample with enough amount of well-preserved tumour will guarantee the performance of the analysis and quality of the results.

\section{Preservation of tumour material}

Currently, the primary source for biomarkers studies are FFPE tumours and normal tissues, stored at room temperature.

Although the use of formaldehyde solution is the universal method of tissue fixation, formaldehyde produces covalent bridges in aqueous solutions and interacts with the - $\mathrm{NH} 2$ groups of proteins, forming cross-linked methylene bridges; the tertiary and quaternary conformations of these bridges are reversible (epitope retrieval), and they interact with DNA by forming hydroxy methylene bridges between two amino groups. In addition, treatment with formaldehyde can produce aberrant mutations by the formation of apurinic and apyrimidinic sites, DNA degradation and cross-linking of cytosines and has recently been considered carcinogenic. Therefore, alternative fixatives have been developed to improve the preservation of nucleic acids. Among these, PAXgene ${ }^{\circledR}$ Tissue Fix (PreAnalytix GmbH Hombrechtikon, Switzerland) and glyoxal acid-free (GAF) stand out $[57,58]$. The prolonged storage of paraffin blocks at room temperature causes the constant degradation of the nucleic acids regardless of the type of fixative used. To slow this degradation process, the blocks should be stored at $4{ }^{\circ} \mathrm{C}$ or frozen [59].

\section{Minimum sufficient quantity}

It is crucial to select tumour material through macro- or microdissection to avoid contamination with normal tissue. To guarantee results, a tumour cell content $10 \%$ higher than normal cell content is considered optimal, thus avoiding the possibility of false results. Currently, with the latest generation of sequencing technologies, a threshold of $5 \%$ could be established. 
The ideal study sample contains the greatest possible number of tumour cells. Thus, it is preferable to compare a resected piece of CRC with the content of a diagnostic endoscopic biopsy or cytological material [60].

\section{Which techniques are most appropriate for the determination of each biomarker?}

Table 1 summarizes the most important biomarkers in CRC along with the recommended techniques to evaluate them and whether its performance is optional or mandatory.

\section{RAS mutations}

Currently available technologies for mutational analysis of the KRAS and NRAS genes have not been significantly modified compared to the last guide [61, 62], except for the incorporation of the mutational status of the BRAF gene [25], as reflected in Table 2.

A large number of laboratories continue to use molecular techniques based on sequencing as confirmation techniques of mutations (Sanger sequencing and pyrosequencing) or as screening techniques based on NGS, where different platforms allow these determinations to be performed simultaneously in both clinical trials and in research studies as well as in the assistance activities of several molecular pathology laboratories in Europe [63]. However, the vast majority of laboratories have focused their activity on the use of specific assays to detect specific alterations in these genes (KRAS, NRAS and BRAF) using commercial kits by Conformité Européenne-In Vitro
Diagnostic (CE-IVD) at the expense of the tests developed by each laboratory (laboratory developed test [LDTs]), whose use is limited in Spain in comparison with other European countries, such as Holland and Germany [64].

Notably, many of the kits used to determine KRAS/NRAS mutations do not determine BRAF mutations simultaneously; therefore, many laboratories have had to modify their workflows as well as combine molecular techniques to analyse these mutations sequentially (e.g., first, $K R A S$ gene mutations are analysed, then NRAS gene mutations and finally $B R A F$ gene mutations), which increases response times, sample manipulation and complexity for obtaining these results.

In the case of the BRAF gene, the majority of the mutations focus on the valine amino acid at position 600 , which can be affected in multiple ways (V600E/E2/K/D/R or M); however, given that the vast majority correspond to the $\mathrm{p}$. V600E change, this mutation can be detected by a specific antibody (Clone VE1) via IHC. However, although this technique has shown high sensitivity and analytical specificity in different studies [65, 66], confirmation is currently required by a molecular technique.

In recent years, there has been an increase in the use of commercial point of care (POC) techniques that minimize and automate the process of determining gene mutations, significantly reducing response times, reducing the risk of obtaining false positives/negatives and avoiding DNA extraction because analyses can be performed directly with an FFPE sample, with minimum manipulation by the technical staff and with validated results against conventional

Table 1 Main biomarkers used in CRC

\begin{tabular}{lll}
\hline Biomarker & Technique & Indication \\
\hline CRC-universal & & Required \\
MSI & IHC and/or MSI analysis by qPCR, bPCR, NGS & Optional \\
Immunoscore or immunodensity & IHC and/or digital score & Required \\
CRC-localized & & Optional \\
MSI & IHC and/or PCR and MSI analysis & Required \\
Immunoscore or immunodensity & IHC and/or digital score & Required \\
CRC-advanced & & Required \\
MSI & IHC and/or PCR and MSI analysis & Optional \\
Extended $R A S$ & KRAS, NRAS & Optional \\
$B-R A F$ & V600E & Optional in MSI, $M L H 1$ hyper- \\
$H E R 2$ & V600E2/K/D/R or M & methylation and $R A S W T$ \\
Rearrangements of: NTRK1; NTRK2; & IHC / FISH / SISH & Optional for patient monitorization \\
NTRK3 & IHC and FISH, NGS, RT-PCR, NanoString ${ }^{2}$ & \\
Liquid biopsy & qPCR, dPCR, NGS, cfDNA Idylla & \\
\hline
\end{tabular}

cfDNA cell fee DNA, FISH fluorescent in situ hybridization, IHC immunohistochemistry, MSI microsatellite instability, NGS next-generation sequencing, PCR polymerase chain reaction; $b P C R$ bridging PCR, $d P C R$ digital PCR, $q P C R$ quantitative PCR, RT-PCR real-time PCR, SISH silver in situ hybridization, $W T$ wild type 
Table 2 Molecular techniques employed in CRC

\begin{tabular}{|c|c|c|}
\hline Techniques available & $\begin{array}{l}\text { Sensitivity ( } \% \\
\text { mutated DNA) }\end{array}$ & Characteristics \\
\hline \multicolumn{3}{|c|}{ Mutational study of isolated genes $(K R A S, N R A S$ and $B R A F)$} \\
\hline \multicolumn{3}{|c|}{ Methods of direct sequencing } \\
\hline Sanger method & 25 & $\begin{array}{l}\text { Detects any mutation } \\
\text { Requires a greater amount of mutated DNA } \\
\text { Inexpensive }\end{array}$ \\
\hline Pyrosequencing & $5-10$ & $\begin{array}{l}\text { Commercial trial available } \\
\text { Requires pyrosequencer }\end{array}$ \\
\hline NGS & $1-5$ & $\begin{array}{l}\text { Commercial trial available } \\
\text { Requires specific equipment } \\
\text { Requires experience in molecular biology }\end{array}$ \\
\hline PCR-fragment analysis & $1-5$ & $\begin{array}{l}\text { Commercial trial available } \\
\text { Requires specific equipment } \\
\text { Requires experience in molecular biology }\end{array}$ \\
\hline \multicolumn{3}{|l|}{ Quantitative RT-PCR } \\
\hline TaqMan $®$ PCR & 10 & $\begin{array}{l}\text { Only detects specific mutations } \\
\text { No commercial trial } \\
\text { Requires real-time thermocycler }\end{array}$ \\
\hline Scorpions-ARMS & 1 & $\begin{array}{l}\text { Only detects specific mutations } \\
\text { Commercial trial available } \\
\text { Requires real-time thermocycler }\end{array}$ \\
\hline \multicolumn{3}{|c|}{ Mutated allele enrichment techniques } \\
\hline PNA-LNA PCR clamp & $0,1-1$ & $\begin{array}{l}\text { Only detects specific mutations } \\
\text { Requires non-commercial LNA probes } \\
\text { Requires experience in molecular biology }\end{array}$ \\
\hline COLD-PCR & $0,1-1$ & $\begin{array}{l}\text { Requires experience in molecular biology } \\
\text { Can be associated with sequencing and pyrosequencing techniques }\end{array}$ \\
\hline PCR-RFLP & 5 & $\begin{array}{l}\text { Only detects mutations that generate a restriction site } \\
\text { Commercial trial available }\end{array}$ \\
\hline DHPLC & 1 & $\begin{array}{l}\text { Detects any mutation } \\
\text { Special equipment required } \\
\text { Requires experience in HPLC }\end{array}$ \\
\hline HRM & 1 & $\begin{array}{l}\text { Detects any mutation } \\
\text { Requires specific equipment } \\
\text { Requires experience in molecular biology }\end{array}$ \\
\hline PCR + hybridization & $1-5$ & $\begin{array}{l}\text { Only detects specific mutations } \\
\text { Commercial trial available } \\
\text { Requires specific equipment (in the case of hybridization in arrays or strips if there is } \\
\text { a large volume) } \\
\text { Requires experience in molecular biology }\end{array}$ \\
\hline \multicolumn{3}{|c|}{ Direct techniques for determining $\boldsymbol{R A S}$} \\
\hline Point of care & $1-5$ & $\begin{array}{l}\text { Only detects specific mutations } \\
\text { Requires specific equipment } \\
\text { Does not require experience in molecular biology }\end{array}$ \\
\hline IHQ $B R A F(\mathrm{VE} 1)$ & & $\begin{array}{l}\text { Only detects the mutation } \mathrm{V} 600 \mathrm{E} \text { of } B R A F \\
\text { Requires specific automation equipment } \\
\text { Does not require experience in molecular biology }\end{array}$ \\
\hline \multicolumn{3}{|l|}{ MSI study } \\
\hline IHQ & & $\begin{array}{l}\text { Detects mutations in the } M L H 1, M H S 2, M S H 3 \text { and } P M S 2 \text { genes } \\
\text { Requires specific automation equipment } \\
\text { Has internal controls for each staining }\end{array}$ \\
\hline PCR + MSI analysis & $1-5$ & $\begin{array}{l}\text { Detects MSI alterations } \\
\text { Commercial trial available } \\
\text { Requires sequencing and experience in molecular biology }\end{array}$ \\
\hline
\end{tabular}


Table 2 (continued)

\begin{tabular}{|c|c|c|}
\hline Techniques available & $\begin{array}{l}\text { Sensitivity (\% } \\
\text { mutated DNA) }\end{array}$ & Characteristics \\
\hline NGS & $1-5$ & $\begin{array}{l}\text { Available commercial trials pending validation } \\
\text { Requires specific equipment } \\
\text { Requires experience in molecular biology }\end{array}$ \\
\hline \multicolumn{3}{|c|}{ HER2 amplification study } \\
\hline IHQ & & $\begin{array}{l}\text { High concordance with gene amplification in those overexpressed } \\
\text { Requires specific automation equipment } \\
\text { Has interpretation guides }\end{array}$ \\
\hline In situ hybridization & $1-5$ & $\begin{array}{l}\text { Detects amplifications in a specific way } \\
\text { Commercial trials available } \\
\text { Requires experience and fluorescence microscope (FISH) }\end{array}$ \\
\hline NGS & $1-5$ & $\begin{array}{l}\text { Available commercial trials pending validation } \\
\text { Requires specific equipment } \\
\text { Requires experience in molecular biology }\end{array}$ \\
\hline \multicolumn{3}{|c|}{$N T R K$ rearrangements study } \\
\hline IHQ & & $\begin{array}{l}\text { Overexpression associated with the presence of rearrangements of any of the three } \\
\text { genes (NTRK1, NTRK } 2 \text { and NRTK3) } \\
\text { Requires specific automation equipment } \\
\text { Confirmation with additional molecular techniques }\end{array}$ \\
\hline In situ hybridization & $1-5$ & $\begin{array}{l}\text { Detects amplifications in a specific way } \\
\text { Commercial trials available } \\
\text { Requires experience and fluorescence microscope (FISH) and the use of three probes }\end{array}$ \\
\hline NGS & $1-5$ & $\begin{array}{l}\text { Available commercial trials pending validation } \\
\text { Requires specific equipment } \\
\text { Requires experience in molecular biology }\end{array}$ \\
\hline
\end{tabular}

ARMS mutation system refractory to amplification, COLD-PCR coamplification at lower denaturation temperatures, $D H P L C$ denaturing highperformance liquid chromatography, FISH fluorescent in situ hybridization, $H P L C$ high-performance liquid chromatography, $H R M$ high-resolution fusion, $I H C$ immunohistochemistry, $M S I$ microsatellite instability, NGS next-generation sequencing, $P C R$ polymerase chain reaction, $P N A$ $L N A$ peptide nucleic acid-blocked nucleic acid, $R F L P$ restriction fragment length polymorphisms, $R T$ - $P C R$ real-time PCR

techniques and NGS [67], even using DNA extracted from paraffin-embedded samples [68].

In the coming years, it is believed that the use of specific algorithms based on the use of artificial intelligence will increase and be used to analyse both radiological and HE images, which will produce $R A S$ analyses with greater precision $[69,70]$.

\section{MSI}

Other indispensable markers in patients with CRC are $M M R$ deficiency and the presence of MSI for identifying patients with Lynch syndrome with prognostic purpose and to predict the response to different immunotherapeutic treatments.

For this purpose, in the majority of pathology laboratories, IHC analysis of the four repair genes (MLH1, MSH2, MSH6 and PMS2) is performed; however, because the encoded proteins act in tandem, different groups have proposed that only IHQ determination of $M L H 1$ and $M S H 2$ can be used as a screening technique [71].

In addition, PCR techniques have been used for the detection of MSI. When developing the methodology, we began using a panel of microsatellites (Bethesda panel) composed of markers that detect single base alterations (BAT25 and BAT26) as well as three dinucleotide markers (D2S123, D5S346 and D17S250), but recently, new mononucleotide satellites have been incorporated, which have shown better prediction capabilities than those of previous dinucleotides [72].

Finally, both recently implemented NGS techniques and new POC tools allow the determination of MSI with new satellites included in their panels and are being validated in different studies [73].

\section{Alterations in HER2}

The determination of the amplification of HER2 in CRC has generated great interest because of its prognostic and predictive value of response to specific treatments because approximately $3 \%$ of patients have such alterations [74].

The methods of analysis are the same as those used in breast and gastric cancers, where IHC (HercepTest ${ }^{\circledR}$ or Clone 4B5) stands out, showing great concordance with the gene amplification detected by FISH or in silver in situ hybridization (SISH) [34]. Currently, both the determination of the copy number alterations (CNAs) in a tumour by 
NGS techniques and the quantification of the levels of HER2 mRNA are being validated in different studies before their implementation in routine healthcare [39].

\section{NTRK rearrangements}

The rearrangements of the NTRK1, NTRK 2 and NTRK 3 genes are of special relevance in CRC because, although their prevalence is very low (1.5\%) [39], these alterations are associated with the presence of MSI, hypermethylated $M L H 1$ and native RAS [75]. In addition, it is important to mention that they have a great predictive value of response to TRK inhibitors. The classical techniques for the detection of NTRK alterations are generally performed by IHC with pan-TRK clones as screening, with subsequent confirmation by different tests (FISH, NGS, RT-PCR or NanoString ${ }^{\circledR}$ ); however, each one has its limitations [76].

\section{What is the current and future role of NGS in CRC?}

The implementation of NGS in the study of CRC will allow, in the future, the diagnosis of Lynch syndrome through the mutational study of the MMR and EPCAM genes [77] and will guide treatment by detecting the mutations of the main genes involved in the pathways of CRC carcinogenesis, such as $R A S$ and $B R A F$, as well as the genes associated with targeted treatment, such as $H E R 2$. In addition, it will be possible to classify CRC into molecular subtypes (CMS1, CMS2, CMS3 and CMS4) with different biological behaviours and therapeutic responses, which will open the possibility of designing personalized treatment [9]. Likewise, NGS will allow the identification of the tumour hypermutation status, which will guarantee the efficacy of immunotherapy [78].

Furthermore, through the study of ctDNA, it will be possible to monitor response to treatment, anticipate the appearance of local recurrence and metastasis, and detect resistance to ongoing treatment [79].

Finally, the possibility of implementing the combination of different molecular tools in the diagnostic routine will also improve the quality of tumour samples [68], without forgetting that IHC continues to be an indispensable diagnostic technique [80].

\section{What are the current and future roles of liquid biopsy in CRC?}

A liquid biopsy is based on the analysis of a biological liquid, usually blood, but also cerebrospinal fluid or urine, to reveal characteristics of a cancer, such as circulating tumour cells (CTCs), free nucleic acids (DNA or RNA), exosomes or tumour-derived platelets. The quantification of CTCs in peripheral blood has been shown to have prognostic value with a threshold level above or below three cells. The possibility of extracting DNA from these cells for NGS has been recently evaluated [81].

The most developed option in liquid biopsy is the study of ctDNA in peripheral blood. The biomarker with the greatest impact on CRC is the mutation in the RAS oncogene, including $K R A S$ and $N R A S$, in exons 2, 3 and 4, which indicates patients who may be candidates for treatment with anti-EGFR antibodies in case of the native or non-mutated sequence. This technique has been studied using tumour tissue as a comparison. Different publications have confirmed that using high sensitivity molecular techniques [82], the concordance between the analyses performed on tumour tissue and peripheral blood exceeds $90 \%$ [83]. Correctly selecting the analysis technique is critical. Liquid biopsy has two very significant advantages compared to tissue biopsy: (i) it indicates the heterogeneity of the tumour and (ii) it is a real-time reflection of the molecular profile, which allows determining the dynamic evolution of the tumour.

Several studies have observed the convenience of using liquid biopsy in the early determination of response in patients with $R A S$ mutations, in whom during the course of treatment the basal mutation was not detected, and in patients with a RAS native sequence, in whom during treatment a $R A S$ mutation is detected, predicting, presumably, the onset of radiological progression of the disease. The determination of $B R A F$ mutations can be another important application of liquid biopsy because it allows monitoring patients with CRC with this alteration [84].

Recent research has opened the way to new uses of liquid biopsy. Some studies have proposed its possible use for the early diagnosis of CRC; however, this option is still very preliminary and, for the moment, lacks an adequate cost-effectiveness relationship as a population screening technique [85]. Finally, the identification of low-incidence molecular alterations in CRC, such as the presence of HER2 amplification or fusions that affect $N T R K$, could be evaluated via ctDNA by mass sequencing platforms [86].

\section{Conclusions}

In recent decades, significant progress has been made in understanding the molecular characteristics of CRC and in the identification of specific mutations that have allowed the development of new prognostic and predictive biomarkers in the different stages of the disease. These advances, together with those achieved through pathological knowledge, have justified a new edition of this guide.

With respect to the susceptibility markers of hereditary CRC, this panel recommends the analysis of MSI and/ 
or IHC in all patients diagnosed with CRC. In addition, the germinal study of $M M R$ genes should continue in patients with MSI and/or loss of repair protein expression. In localized stages, the determination of MSI as a prognostic marker is required, especially in stage II CRC. The standardized implementation of genomic platforms is not recommended due to the lack of predictive value of response to chemotherapy.

In patients with advanced CRC, it is essential to determine extended $R A S$ mutations, the BRAF V600E mutation and the MSI status, which is usually performed via IHC for MLH1, MSH2, MSH6 and PMS2. The determination of extended $R A S$ mutations is mandatory before making therapeutic decisions (I-A). The RAS analysis should include $H R A S, K R A S$ and NRAS, exons 2 (codons 12 and 13), 3 (codons 59 and 61) and 4 , as negative predictive factors of the anti-EGFR response. The BRAF V600E mutation is required due to its recognized negative prognostic value (I-A) and, recently, as a predictive marker of specific biological treatments (cetuximab, encorafenib and binimetinib). The determination of MSI acquires predictive value in advanced CRC for immunotherapy treatment with pembrolizumab or nivolumab (II-B).

Another recommended marker in advanced CRC is the amplification of HER 2 as a negative predictive marker of anti-EGFR response and as a response marker for dual antiHER2 therapy. Its determination is recommended, at least in native $R A S$ tumours resistant to anti-EGFR. The ALK, ROSI and NTRK fusions, despite their low incidence, have clinical interest due to recent approval for specific treatments.

The greatest contribution to the genetic study of CRC will come from liquid biopsies, with which minimal residual disease can be detected after surgery. This technique reflects tumour heterogeneity and molecular profiles in real time, reporting the dynamic evolution of the tumour. The implementation of NGS will improve genotypic knowledge, the tumour hypermutation status and molecular subtypes. The combination of different molecular tools in the diagnostic routine will improve the diagnosis using and quality of tumour samples.

Acknowledgements The authors are grateful for the editorial assistance of Beatriz Gil-Alberdi of HealthCo (Madrid, Spain) in the production of this manuscript.

Funding SEAP and SEOM have received financial support for this project in the form of unrestricted grants from Bayer, Merck, Pierre Fabre and Roche.

\section{Compliance with ethical standards}

Conflict of interest The authors declare that, when writing and revising the text, they did not know the names of the pharmaceutical companies that provided financial support for this project, so this support has not influenced the content of this article.
Ethical approval (research involving human participants and/or animals) The study has been performed in accordance with the ethical standards of the Declaration of Helsinki and its later amendments. This article does not contain any studies with human participants or animals performed by any of the authors.

Informed consent For this type of study formal consent is not required.

Open Access This article is licensed under a Creative Commons Attribution 4.0 International License, which permits use, sharing, adaptation, distribution and reproduction in any medium or format, as long as you give appropriate credit to the original author(s) and the source, provide a link to the Creative Commons licence, and indicate if changes were made. The images or other third party material in this article are included in the article's Creative Commons licence, unless indicated otherwise in a credit line to the material. If material is not included in the article's Creative Commons licence and your intended use is not permitted by statutory regulation or exceeds the permitted use, you will need to obtain permission directly from the copyright holder. To view a copy of this licence, visit http://creativecommons.org/licenses/by/4.0/.

\section{References}

1. Garcia-Alfonso P, Garcia-Foncillas J, Salazar R, Perez-Segura P, Garcia-Carbonero R, Musulen-Palet E, Cuatrecasas M, Landolfi S, Ramon YCS, Navarro S, Spanish Society of P, Spanish Society of Medical O. Updated guidelines for biomarker testing in colorectal carcinoma: a national consensus of the Spanish Society of Pathology and the Spanish Society of Medical Oncology. Clin Transl Oncol. 2015;17(4):264-73. https://doi.org/10.1007/s1209 4-014-1252-0.

2. DeStefanis RA, Kratz JD, Emmerich PB, Deming DA. Targeted therapy in metastatic colorectal cancer: current standards and novel agents in review. Curr Colorectal Cancer Rep. 2019;15(2):61-9. https://doi.org/10.1007/s11888-019-00430-6.

3. Martinez-Ciarpaglini C, Fernandez-Sellers C, Tarazona N, Rosello S, Huerta M, Roda D, Mongort C, Ferrandez A, Navarro $\mathrm{S}$, Cervantes A. Improving tumour budding evaluation in colon cancer by extending the assessment area in colectomy specimens. Histopathology. 2019. https://doi.org/10.1111/his.13900.

4. Konishi T, Shimada Y, Lee LH, Cavalcanti MS, Hsu M, Smith JJ, Nash GM, Temple LK, Guillem JG, Paty PB, Garcia-Aguilar J, Vakiani E, Gonen M, Shia J, Weiser MR. Poorly differentiated clusters predict colon cancer recurrence: an in-depth comparative analysis of invasive-front prognostic markers. Am J Surg Pathol. 2018;42(6):705-14. https://doi.org/10.1097/PAS.0000000000 001059.

5. Rakislova N, Montironi C, Aldecoa I, Fernandez E, Bombi JA, Jimeno M, Balaguer F, Pellise M, Castells A, Cuatrecasas M. Lymph node pooling: a feasible and efficient method of lymph node molecular staging in colorectal carcinoma. J Transl Med. 2017;15(1):14. https://doi.org/10.1186/s12967-016-1114-3.

6. American Gastroenterological A. American Gastroenterological Association medical position statement: hereditary colorectal cancer and genetic testing. Gastroenterology. 2001;121(1):195-7. https://doi.org/10.1053/gast.2001.25580.

7. Vasen HF, Watson P, Mecklin JP, Lynch HT. New clinical criteria for hereditary nonpolyposis colorectal cancer (HNPCC, Lynch syndrome) proposed by the International Collaborative group on HNPCC. Gastroenterology. 1999;116(6):1453-6. https://doi. org/10.1016/s0016-5085(99)70510-x. 
8. Sepulveda AR, Hamilton SR, Allegra CJ, Grody W, CushmanVokoun AM, Funkhouser WK, Kopetz SE, Lieu C, Lindor NM, Minsky BD, Monzon FA, Sargent DJ, Singh VM, Willis J, Clark J, Colasacco C, Rumble RB, Temple-Smolkin R, Ventura CB, Nowak JA. Molecular biomarkers for the evaluation of colorectal cancer: guideline from the American Society for Clinical Pathology, College of American Pathologists, Association for Molecular Pathology, and American Society of Clinical Oncology. J Mol Diagn. 2017;19(2):187-225. https://doi.org/10.1016/j.jmold x.2016.11.001.

9. Dienstmann R, Salazar R, Tabernero J. Personalizing colon cancer adjuvant therapy: selecting optimal treatments for individual patients. J Clin Oncol. 2015;33(16):1787-96. https://doi. org/10.1200/JCO.2014.60.0213.

10. Taieb J, Kourie HR, Emile JF, Le Malicot K, Balogoun R, Tabernero J, Mini E, Folprecht G, Van Laethem JL, Mulot C, Bouche O, Aparicio T, Michel P, Thaler J, Bridgewater J, Van Cutsem E, Perkins G, Lepage C, Salazar R, Laurent-Puig P, Pan-European Trials in Alimentary Tract Cancer I. Association of prognostic value of primary tumor location in stage III colon cancer with RAS and BRAF mutational status. JAMA Oncol. 2018;4(7):e173695. https://doi.org/10.1001/jamaoncol.2017.3695.

11. Sanz-Pamplona R, Berenguer A, Cordero D, Riccadonna S, Sole X, Crous-Bou M, Guino E, Sanjuan X, Biondo S, Soriano A, Jurman G, Capella G, Furlanello C, Moreno V. Clinical value of prognosis gene expression signatures in colorectal cancer: a systematic review. PLoS ONE. 2012;7(11):e48877. https://doi. org/10.1371/journal.pone.0048877.

12. Niedzwiecki D, Frankel WL, Venook AP, Ye X, Friedman PN, Goldberg RM, Mayer RJ, Colacchio TA, Mulligan JM, Davison TS, O'Brien E, Kerr P, Johnston PG, Kennedy RD, Harkin DP, Schilsky RL, Bertagnolli MM, Warren RS, Innocenti F. Association between results of a gene expression signature assay and recurrence-free interval in patients with stage II colon cancer in cancer and leukemia group B 9581 (alliance). J Clin Oncol. 2016;34(25):3047-53. https://doi.org/10.1200/JCO.2015.65.4699.

13. Gray RG, Quirke P, Handley K, Lopatin M, Magill L, Baehner FL, Beaumont C, Clark-Langone KM, Yoshizawa CN, Lee M, Watson D, Shak S, Kerr DJ. Validation study of a quantitative multigene reverse transcriptase-polymerase chain reaction assay for assessment of recurrence risk in patients with stage II colon cancer. J Clin Oncol. 2011;29(35):4611-9. https://doi.org/10.1200/ JCO.2010.32.8732.

14. Venook AP, Niedzwiecki D, Lopatin M, Ye X, Lee M, Friedman PN, Frankel W, Clark-Langone K, Millward C, Shak S, Goldberg RM, Mahmoud NN, Warren RS, Schilsky RL, Bertagnolli MM. Biologic determinants of tumor recurrence in stage II colon cancer: validation study of the 12-gene recurrence score in cancer and leukemia group B (CALGB) 9581. J Clin Oncol. 2013;31(14):1775-811. https://doi.org/10.1200/ JCO.2012.45.1096.

15. Yamanaka T, Oki E, Yamazaki K, Yamaguchi K, Muro K, Uetake H, Sato T, Nishina T, Ikeda M, Kato T, Kanazawa A, Kusumoto T, Chao C, Lopatin M, Krishnakumar J, Bailey H, Akagi K, Ochiai A, Ohtsu A, Ohashi Y, Yoshino T. 12-gene recurrence score assay stratifies the recurrence risk in stage II/III colon cancer with surgery alone: the SUNRISE Study. J Clin Oncol. 2016;34(24):290613. https://doi.org/10.1200/JCO.2016.67.0414.

16. Yothers G, O'Connell MJ, Lee M, Lopatin M, Clark-Langone KM, Millward C, Paik S, Sharif S, Shak S, Wolmark N. Validation of the 12-gene colon cancer recurrence score in NSABP C-07 as a predictor of recurrence in patients with stage II and III colon cancer treated with fluorouracil and leucovorin (FU/LV) and FU/ LV plus oxaliplatin. J Clin Oncol. 2013;31(36):4512-9. https:// doi.org/10.1200/JCO.2012.47.3116.
17. Pages F, Mlecnik B, Marliot F, Bindea G, Ou FS, Bifulco C, Lugli A, Zlobec I, Rau TT, Berger MD, Nagtegaal ID, Vink-Borger E, Hartmann A, Geppert C, Kolwelter J, Merkel S, Grutzmann R, Van den Eynde M, Jouret-Mourin A, Kartheuser A, Leonard D, Remue C, Wang JY, Bavi P, Roehrl MHA, Ohashi PS, Nguyen LT, Han S, MacGregor HL, Hafezi-Bakhtiari S, Wouters BG, Masucci GV, Andersson EK, Zavadova E, Vocka M, Spacek J, Petruzelka L, Konopasek B, Dundr P, Skalova H, Nemejcova K, Botti G, Tatangelo F, Delrio P, Ciliberto G, Maio M, Laghi L, Grizzi F, Fredriksen T, Buttard B, Angelova M, Vasaturo A, Maby P, Church SE, Angell HK, Lafontaine L, Bruni D, El Sissy C, Haicheur N, Kirilovsky A, Berger A, Lagorce C, Meyers JP, Paustian C, Feng Z, Ballesteros-Merino C, Dijkstra J, van de Water C, van Lent-van Vliet S, Knijn N, Musina AM, Scripcariu DV, Popivanova B, Xu M, Fujita T, Hazama S, Suzuki N, Nagano H, Okuno K, Torigoe T, Sato N, Furuhata T, Takemasa I, Itoh K, Patel PS, Vora HH, Shah B, Patel JB, Rajvik KN, Pandya SJ, Shukla SN, Wang Y, Zhang G, Kawakami Y, Marincola FM, Ascierto PA, Sargent DJ, Fox BA, Galon J. International validation of the consensus Immunoscore for the classification of colon cancer: a prognostic and accuracy study. Lancet. 2018;391(10135):2128-39. https://doi.org/10.1016/S0140-6736(18)30789-X.

18. Wong R, Tie J, Lee M, Cohen J, Wang Y, Li L, Ma S, Christie M, Kosmider S, Tomasetti C, Papadopoulos N, Kinzler KW, Vogelstein B, Gibbs P. The potential role of circulating tumor DNA (ctDNA) in the further investigation of colorectal cancer patients with nonspecific findings on standard investigations. Int J Cancer. 2019;145(2):540-7. https://doi.org/10.1002/ijc.32117.

19. Dalerba P, Sahoo D, Paik S, Guo X, Yothers G, Song N, WilcoxFogel N, Forgo E, Rajendran PS, Miranda SP, Hisamori S, Hutchison J, Kalisky T, Qian D, Wolmark N, Fisher GA, van de Rijn M, Clarke MF. CDX2 as a prognostic biomarker in stage II and stage III colon cancer. N Engl J Med. 2016;374(3):211-22. https://doi. org/10.1056/NEJMoa1506597.

20. Van Cutsem E, Kohne CH, Lang I, Folprecht G, Nowacki MP, Cascinu S, Shchepotin I, Maurel J, Cunningham D, Tejpar S, Schlichting M, Zubel A, Celik I, Rougier P, Ciardiello F. Cetuximab plus irinotecan, fluorouracil, and leucovorin as first-line treatment for metastatic colorectal cancer: updated analysis of overall survival according to tumor KRAS and BRAF mutation status. J Clin Oncol. 2011;29(15):2011-9. https://doi.org/10.1200/ JCO.2010.33.5091.

21. Bokemeyer C, Bondarenko I, Hartmann JT, de Braud F, Schuch G, Zubel A, Celik I, Schlichting M, Koralewski P. Efficacy according to biomarker status of cetuximab plus FOLFOX-4 as firstline treatment for metastatic colorectal cancer: the OPUS study. Ann Oncol. 2011;22(7):1535-46. https://doi.org/10.1093/annon c/mdq632.

22. Douillard JY, Siena S, Cassidy J, Tabernero J, Burkes R, Barugel M, Humblet Y, Bodoky G, Cunningham D, Jassem J, Rivera F, Kocakova I, Ruff P, Blasilska-Morawiec M, Smakal M, Canon JL, Rother M, Oliner KS, Tian Y, Xu F, Sidhu R. Final results from PRIME: randomized phase 3 study of panitumumab with FOLFOX4 for first-line treatment of metastatic colorectal cancer. Ann Oncol. 2014. https://doi.org/10.1093/annonc/mdu141.

23. Arnold D, Lueza B, Douillard JY, Peeters M, Lenz HJ, Venook A, Heinemann V, Van Cutsem E, Pignon JP, Tabernero J, Cervantes A, Ciardiello F. Prognostic and predictive value of primary tumour side in patients with RAS wild-type metastatic colorectal cancer treated with chemotherapy and EGFR directed antibodies in six randomized trials. Ann Oncol. 2017;28(8):1713-29. https ://doi.org/10.1093/annonc/mdx175.

24. NCCN (2019) NCCN Clinical Practice Guidelines in Oncology (NCCN Guidelines $\left.{ }^{\circledR}\right)$ : Colon Cancer Version 4.2018. https ://www.nccn.org/professionals/physician_gls/pdf/colon.pdf. Accessed 2 Jan 2019 
25. Van Cutsem E, Cervantes A, Adam R, Sobrero A, Van Krieken JH, Aderka D, Aranda Aguilar E, Bardelli A, Benson A, Bodoky G, Ciardiello F, D'Hoore A, Diaz-Rubio E, Douillard JY, Ducreux M, Falcone A, Grothey A, Gruenberger T, Haustermans K, Heinemann V, Hoff P, Kohne CH, Labianca R, Laurent-Puig P, Ma B, Maughan T, Muro K, Normanno N, Osterlund P, Oyen WJ, Papamichael D, Pentheroudakis G, Pfeiffer P, Price TJ, Punt C, Ricke J, Roth A, Salazar R, Scheithauer W, Schmoll HJ, Tabernero J, Taieb J, Tejpar S, Wasan H, Yoshino T, Zaanan A, Arnold D. ESMO consensus guidelines for the management of patients with metastatic colorectal cancer. Ann Oncol. 2016;27(8):1386-422. https://doi.org/10.1093/annonc/mdw235.

26. Tran B, Kopetz S, Tie J, Gibbs P, Jiang ZQ, Lieu CH, Agarwal A, Maru DM, Sieber O, Desai J. Impact of BRAF mutation and microsatellite instability on the pattern of metastatic spread and prognosis in metastatic colorectal cancer. Cancer. 2011;117(20):4623-32. https://doi.org/10.1002/cncr.26086.

27. Venderbosch S, Nagtegaal ID, Maughan TS, Smith CG, Cheadle JP, Fisher D, Kaplan R, Quirke P, Seymour MT, Richman SD, Meijer GA, Ylstra B, Heideman DA, de Haan AF, Punt CJ, Koopman M. Mismatch repair status and BRAF mutation status in metastatic colorectal cancer patients: a pooled analysis of the CAIRO, CAIRO2, COIN, and FOCUS studies. Clin Cancer Res. 2014;20(20):5322-30. https://doi.org/10.1158/1078-0432. CCR-14-0332.

28. Kopetz S, Grothey A, Yaeger R, Van Cutsem E, Desai J, Yoshino T, Wasan H, Ciardiello F, Loupakis F, Hong YS, Steeghs N, Guren TK, Arkenau HT, Garcia-Alfonso P, Pfeiffer P, Orlov S, Lonardi S, Elez E, Kim TW, Schellens JHM, Guo C, Krishnan A, Dekervel J, Morris V, Calvo Ferrandiz A, Tarpgaard LS, Braun M, Gollerkeri A, Keir C, Maharry K, Pickard M, Christy-Bittel J, Anderson L, Sandor V, Tabernero J. Encorafenib, binimetinib, and cetuximab in BRAF V600E-mutated colorectal cancer. N Engl J Med. 2019;381(17):1632-43. https://doi.org/10.1056/NEJMoa1908075.

29. Le DT, Uram JN, Wang H, Bartlett BR, Kemberling H, Eyring AD, Skora AD, Luber BS, Azad NS, Laheru D, Biedrzycki B, Donehower RC, Zaheer A, Fisher GA, Crocenzi TS, Lee JJ, Duffy SM, Goldberg RM, de la Chapelle A, Koshiji M, Bhaijee F, Huebner T, Hruban RH, Wood LD, Cuka N, Pardoll DM, Papadopoulos N, Kinzler KW, Zhou S, Cornish TC, Taube JM, Anders RA, Eshleman JR, Vogelstein B, Diaz LA Jr. PD-1 blockade in tumors with mismatch-repair deficiency. N Engl J Med. 2015;372(26):2509-20. https://doi.org/10.1056/NEJMoa1500596.

30. Overman MJ, Lonardi S, Wong KYM, Lenz HJ, Gelsomino F, Aglietta M, Morse MA, Van Cutsem E, McDermott R, Hill A, Sawyer MB, Hendlisz A, Neyns B, Svrcek M, Moss RA, Ledeine JM, Cao ZA, Kamble S, Kopetz S, Andre T. Durable clinical benefit with nivolumab plus ipilimumab in DNA mismatch repairdeficient/microsatellite instability-high metastatic colorectal cancer. J Clin Oncol. 2018;36(8):773-9. https://doi.org/10.1200/ JCO.2017.76.9901.

31. Cancer Genome Atlas N. Comprehensive molecular characterization of human colon and rectal cancer. Nature. 2012;487(7407):330-7. https://doi.org/10.1038/nature11252.

32. Richman SD, Southward K, Chambers P, Cross D, Barrett J, Hemmings G, Taylor M, Wood H, Hutchins G, Foster JM, Oumie A, Spink KG, Brown SR, Jones M, Kerr D, Handley K, Gray R, Seymour M, Quirke P. HER2 overexpression and amplification as a potential therapeutic target in colorectal cancer: analysis of 3256 patients enrolled in the QUASAR, FOCUS and PICCOLO colorectal cancer trials. J Pathol. 2016;238(4):562-70. https://doi. org/10.1002/path.4679.

33. La Salvia A, Lopez-Gomez V, Garcia-Carbonero R. HER2-targeted therapy: an emerging strategy in advanced colorectal cancer. Expert Opin Investig Drugs. 2019;28(1):29-38. https://doi. org/10.1080/13543784.2019.1555583.
34. Valtorta E, Martino C, Sartore-Bianchi A, Penaullt-Llorca F, Viale G, Risio M, Rugge M, Grigioni W, Bencardino K, Lonardi S, Zagonel V, Leone F, Noe J, Ciardiello F, Pinto C, Labianca R, Mosconi S, Graiff C, Aprile G, Frau B, Garufi C, Loupakis F, Racca P, Tonini G, Lauricella C, Veronese S, Truini M, Siena S, Marsoni S, Gambacorta M. Assessment of a HER2 scoring system for colorectal cancer: results from a validation study. Mod Pathol. 2015;28(11):1481-91. https://doi.org/10.1038/modpa thol.2015.98.

35. Sartore-Bianchi A, Trusolino L, Martino C, Bencardino K, Lonardi S, Bergamo F, Zagonel V, Leone F, Depetris I, Martinelli E, Troiani T, Ciardiello F, Racca P, Bertotti A, Siravegna G, Torri V, Amatu A, Ghezzi S, Marrapese G, Palmeri L, Valtorta E, Cassingena A, Lauricella C, Vanzulli A, Regge D, Veronese S, Comoglio PM, Bardelli A, Marsoni S, Siena S. Dual-targeted therapy with trastuzumab and lapatinib in treatment-refractory, KRAS codon 12/13 wild-type, HER2-positive metastatic colorectal cancer (HERACLES): a proof-of-concept, multicentre, openlabel, phase 2 trial. Lancet Oncol. 2016;17(6):738-46. https://doi. org/10.1016/S1470-2045(16)00150-9.

36. Meric-Bernstam F, Hurwitz H, Raghav KPS, McWilliams RR, Fakih M, VanderWalde A, Swanton C, Kurzrock R, Burris H, Sweeney C, Bose R, Spigel DR, Beattie MS, Blotner S, Stone A, Schulze K, Cuchelkar V, Hainsworth J. Pertuzumab plus trastuzumab for HER2-amplified metastatic colorectal cancer (MyPathway): an updated report from a multicentre, open-label, phase 2a, multiple basket study. Lancet Oncol. 2019;20(4):518-30. https:// doi.org/10.1016/S1470-2045(18)30904-5.

37. Yoshino T, Iwata H, Tamura K, Takahashi S, Redfern C, Modi S, Doi T, Kawakami H, Taniguchi H, Takashima A, Yamaguchi K, Fisher J, Li B, Saito K, Fujisaki Y, Sugihara M, Tsurutani J. 563PUpdated results of phase I study of trastuzumab deruxtecan (DS-8201a) in HER2-expressing advanced colorectal cancer. Ann Oncol. 2018. https://doi.org/10.1093/annonc/mdy281.109.

38. Madison R, Pietrantonio F, Juckett L, Cremolini C, Chung J, Albacker LA, Miller VA, Klempner SJ, Resnick MB, Yakirevich E, Ou S-HI, Fakih M, Schrock AB, Ross JS, Ali SM. 457PDKinase fusions in colorectal cancers: a unique biologic subset. Ann Oncol. 2018. https://doi.org/10.1093/annonc/mdy281.005.

39. Pietrantonio F, Di Nicolantonio F, Schrock AB, Lee J, Tejpar S, Sartore-Bianchi A, Hechtman JF, Christiansen J, Novara L, Tebbutt N, Fuca G, Antoniotti C, Kim ST, Murphy D, Berenato R, Morano F, Sun J, Min B, Stephens PJ, Chen M, Lazzari L, Miller VA, Shoemaker R, Amatu A, Milione M, Ross JS, Siena S, Bardelli A, Ali SM, Falcone A, de Braud F, Cremolini C. ALK, ROS1, and NTRK rearrangements in metastatic colorectal cancer. J Natl Cancer Inst. 2017. https://doi.org/10.1093/jnci/djx089.

40. Pietrantonio F, Di Nicolantonio F, Schrock AB, Lee J, Morano F, Fuca G, Nikolinakos P, Drilon A, Hechtman JF, Christiansen J, Gowen K, Frampton GM, Gasparini P, Rossini D, Gigliotti C, Kim ST, Prisciandaro M, Hodgson J, Zaniboni A, Chiu VK, Milione M, Patel R, Miller V, Bardelli A, Novara L, Wang L, Pupa SM, Sozzi G, Ross J, Di Bartolomeo M, Bertotti A, Ali S, Trusolino L, Falcone A, de Braud F, Cremolini C. RET fusions in a small subset of advanced colorectal cancers at risk of being neglected. Ann Oncol. 2018;29(6):1394-401. https://doi.org/10.1093/annon c/mdy090.

41. Amin MB, Edge S, Greene F, Byrd DR, Brookland RK, Washington MK, Gershenwald JE, Compton CC, Hess KR, Sullivan DC, Jessup JM, Brierley JD, Gaspar LE, Schilsky RL, Balch CM. AJCC cancer staging manual. 8th ed. New York: American Joint Commission on Cancer Springer International Publishing; 2017.

42. Nakamura T, Mitomi H, Kanazawa H, Ohkura Y, Watanabe M. Tumor budding as an index to identify high-risk patients with stage II colon cancer. Dis Colon Rectum. 2008;51(5):568-72. https://doi.org/10.1007/s10350-008-9192-9. 
43. van Wyk HC, Park J, Roxburgh C, Horgan P, Foulis A, McMillan DC. The role of tumour budding in predicting survival in patients with primary operable colorectal cancer: a systematic review. Cancer Treat Rev. 2015;41(2):151-9. https://doi.org/10.1016/j. ctrv.2014.12.007.

44. De Smedt L, Palmans S, Sagaert X. Tumour budding in colorectal cancer: what do we know and what can we do? Virchows Arch. 2016;468(4):397-408. https://doi.org/10.1007/s0042 8-015-1886-5.

45. Koelzer VH, Zlobec I, Lugli A. Tumor budding in colorectal cancer-ready for diagnostic practice? Hum Pathol. 2016;47(1):4-19. https://doi.org/10.1016/j.humpath.2015.08.007.

46. Lugli A, Kirsch R, Ajioka Y, Bosman F, Cathomas G, Dawson H, El Zimaity H, Flejou JF, Hansen TP, Hartmann A, Kakar S, Langner C, Nagtegaal I, Puppa G, Riddell R, Ristimaki A, Sheahan K, Smyrk T, Sugihara K, Terris B, Ueno H, Vieth M, Zlobec I, Quirke P. Recommendations for reporting tumor budding in colorectal cancer based on the International Tumor Budding Consensus Conference (ITBCC) 2016. Mod Pathol. 2017;30(9):1299-311. https://doi.org/10.1038/modpa thol.2017.46.

47. Rogers AC, Gibbons D, Hanly AM, Hyland JM, O'Connell PR, Winter DC, Sheahan K. Prognostic significance of tumor budding in rectal cancer biopsies before neoadjuvant therapy. Mod Pathol. 2014;27(1):156-62. https://doi.org/10.1038/modpathol.2013.124.

48. Rogers AC, Winter DC, Heeney A, Gibbons D, Lugli A, Puppa G, Sheahan K. Systematic review and meta-analysis of the impact of tumour budding in colorectal cancer. $\mathrm{Br} \mathrm{J}$ Cancer. 2016;115(7):831-40. https://doi.org/10.1038/bjc.2016.274.

49. Compton C.C., Tanabe K K, Savarese D M (2015) UptoDate: pathology and prognostic determinants of colorectal cancer. https ://www.uptodate.com/contents/pathology-and-prognostic-deter minants-of-colorectal-cancer. Accessed 15 May 2019

50. Schmoll HJ, Van Cutsem E, Stein A, Valentini V, Glimelius B, Haustermans K, Nordlinger B, van de Velde CJ, Balmana J, Regula J, Nagtegaal ID, Beets-Tan RG, Arnold D, Ciardiello F, Hoff P, Kerr D, Kohne CH, Labianca R, Price T, Scheithauer W, Sobrero A, Tabernero J, Aderka D, Barroso S, Bodoky G, Douillard JY, El Ghazaly H, Gallardo J, Garin A, Glynne-Jones R, Jordan K, Meshcheryakov A, Papamichail D, Pfeiffer P, Souglakos I, Turhal S, Cervantes A. ESMO Consensus Guidelines for management of patients with colon and rectal cancer: a personalized approach to clinical decision making. Ann Oncol. 2012;23(10):2479-516. https://doi.org/10.1093/annonc/mds236.

51. van de Velde CJ, Boelens PG, Borras JM, Coebergh JW, Cervantes A, Blomqvist L, Beets-Tan RG, van den Broek CB, Brown G, Van Cutsem E, Espin E, Haustermans K, Glimelius B, Iversen LH, van Krieken JH, Marijnen CA, Henning G, Gore-Booth J, Meldolesi E, Mroczkowski P, Nagtegaal I, Naredi P, Ortiz H, Pahlman L, Quirke P, Rodel C, Roth A, Rutten H, Schmoll HJ, Smith JJ, Tanis PJ, Taylor C, Wibe A, Wiggers T, Gambacorta MA, Aristei C, Valentini V. EURECCA colorectal: multidisciplinary management: European consensus conference colon and rectum. Eur J Cancer. 2014;50(1):e1-e34. https://doi.org/10.1016/j. ejca.2013.06.048.

52. Vieth M, Quirke P, Lambert R, von Karsa L, Risio M, International Agency for Research on C. European guidelines for quality assurance in colorectal cancer screening and diagnosis First Edition-Annotations of colorectal lesions. Endoscopy. 2012;44(Suppl 3):SE131-139. https://doi.org/10.1055/s-0032-1309798.

53. Watanabe T, Itabashi M, Shimada Y, Tanaka S, Ito Y, Ajioka Y, Hamaguchi T, Hyodo I, Igarashi M, Ishida H, Ishiguro M, Kanemitsu Y, Kokudo N, Muro K, Ochiai A, Oguchi M, Ohkura Y, Saito Y, Sakai Y, Ueno H, Yoshino T, Fujimori T, Koinuma N, Morita T, Nishimura G, Sakata Y, Takahashi K, Takiuchi H, Tsuruta O, Yamaguchi T, Yoshida M, Yamaguchi N, Kotake K,
Sugihara K, Japanese Society for Cancer of the C, Rectum. Japanese Society for Cancer of the Colon and Rectum (JSCCR) guidelines 2010 for the treatment of colorectal cancer. Int J Clin Oncol. 2012;17(1):1-29. https://doi.org/10.1007/s10147-011-0315-2.

54. Rahbari NN, Bork U, Motschall E, Thorlund K, Buchler MW, Koch M, Weitz J. Molecular detection of tumor cells in regional lymph nodes is associated with disease recurrence and poor survival in node-negative colorectal cancer: a systematic review and meta-analysis. J Clin Oncol. 2012;30(1):60-70. https://doi. org/10.1200/JCO.2011.36.9504

55. Aldecoa I, Atares B, Tarragona J, Bernet L, Sardon JD, Pereda T, Villar C, Mendez MC, Gonzalez-Obeso E, Elorriaga K, Alonso GL, Zamora J, Planell N, Palacios J, Castells A, Matias-Guiu $\mathrm{X}$, Cuatrecasas M. Molecularly determined total tumour load in lymph nodes of stage I-II colon cancer patients correlates with high-risk factors. A multicentre prospective study. Virchows Arch. 2016;469(4):385-94. https://doi.org/10.1007/s00428-016-1990-1.

56. Yamamoto H, Tomita N, Inomata M, Furuhata T, Miyake $Y$, Noura S, Kato T, Murata K, Hayashi S, Igarashi S, Itabashi M, Kameoka S, Matsuura N. OSNA-assisted molecular staging in colorectal cancer: a prospective multicenter trial in Japan. Ann Surg Oncol. 2016;23(2):391-6. https://doi.org/10.1245/s 1043 4-015-4880-x

57. Hognas G, Kivinummi K, Kallio HML, Hieta R, Ruusuvuori P, Koskenalho A, Kesseli J, Tammela TLJ, Riikonen J, Ilvesaro J, Kares S, Hirvikoski PP, Laurila M, Mirtti T, Nykter M, Kujala PM, Visakorpi T, Tolonen T, Bova GS. Feasibility of prostate PAXgene fixation for molecular research and diagnostic surgical pathology: comparison of matched fresh frozen, FFPE, and PFPE tissues. Am J Surg Pathol. 2018;42(1):103-15. https://doi. org/10.1097/PAS.0000000000000961.

58. Bussolati G, Annaratone L, Berrino E, Miglio U, Panero M, Cupo M, Gugliotta P, Venesio T, Sapino A, Marchio C. Acid-free glyoxal as a substitute of formalin for structural and molecular preservation in tissue samples. PLoS ONE. 2017;12(8):e0182965. https://doi.org/10.1371/journal.pone.0182965.

59. Groelz D, Viertler C, Pabst D, Dettmann N, Zatloukal K. Impact of storage conditions on the quality of nucleic acids in paraffin embedded tissues. PLoS ONE. 2018;13(9):e0203608. https://doi. org/10.1371/journal.pone.0203608.

60. Bellevicine C, Malapelle U, Vigliar E, Pisapia P, Vita G, Troncone G. How to prepare cytological samples for molecular testing. J Clin Pathol. 2017;70(10):819-26. https://doi.org/10.1136/jclin path-2017-204561.

61. Douillard JY, Oliner KS, Siena S, Tabernero J, Burkes R, Barugel M, Humblet Y, Bodoky G, Cunningham D, Jassem J, Rivera F, Kocakova I, Ruff P, Blasinska-Morawiec M, Smakal M, Canon JL, Rother M, Williams R, Rong A, Wiezorek J, Sidhu R, Patterson SD. Panitumumab-FOLFOX4 treatment and RAS mutations in colorectal cancer. N Engl J Med. 2013;369(11):1023-34. https:// doi.org/10.1056/NEJMoa1305275.

62. Karapetis CS, Khambata-Ford S, Jonker DJ, O'Callaghan CJ, Tu D, Tebbutt NC, Simes RJ, Chalchal H, Shapiro JD, Robitaille S, Price TJ, Shepherd L, Au HJ, Langer C, Moore MJ, Zalcberg JR. $\mathrm{K}$-ras mutations and benefit from cetuximab in advanced colorectal cancer. N Engl J Med. 2008;359(17):1757-65. https://doi. org/10.1056/NEJMoa0804385.

63. Richman SD, Fairley J, Butler R, Deans ZC. RAS screening in colorectal cancer: a comprehensive analysis of the results from the UK NEQAS colorectal cancer external quality assurance schemes (2009-2016). Virchows Arch. 2017;471(6):721-9. https://doi. org/10.1007/s00428-017-2162-7.

64. Tack V, Ligtenberg MJL, Siebers AG, Rombout PDM, Dabir PD, Weren RDA, van Krieken J, Dequeker EMC. RAS testing for colorectal cancer patients is reliable in European laboratories that pass 
external quality assessment. Virchows Arch. 2018;472(5):717-25. https://doi.org/10.1007/s00428-017-2291-z.

65. Dvorak K, Higgins A, Palting J, Cohen M, Brunhoeber P. Immunohistochemistry with anti-BRAF V600E (VE1) mouse monoclonal antibody is a sensitive method for detection of the BRAF V600E mutation in colon cancer: evaluation of 120 cases with and without KRAS mutation and literature review. Pathol Oncol Res. 2019;25(1):349-59. https://doi.org/10.1007/s12253-017-0344-x.

66. Gonzalez-Colunga KJ, Lino-Silva LS, Salcedo-Hernandez RA, Ruiz-Garcia EB, Zepeda-Najar C. BRAF V600E expression by immunohistochemistry in colon cancer and clinico-pathologic features associated with BRAF-mutated colonic cancers in Mexican patients. J Gastrointest Cancer. 2019. https://doi.org/10.1007/ s12029-018-00191-9.

67. Prieto-Potin I, Montagut C, Bellosillo B, Evans M, Smith M, Melchior L, Reiltin W, Bennett M, Pennati V, Castiglione F, Burrig KF, Cooper U, Dockhorn-Dworniczak B, Rossenbach C, LunaAguirre CM, Barrera-Saldana HA, Machado JC, Costa JL, Yacobi R, Tabibian-Keissar H, Buglioni S, Ronchetti L, Douglas-Berger L, Dubbink HJ, Alorini M, Sabourin JC, Rojo F. Multicenter evaluation of the idylla NRAS-BRAF mutation test in metastatic colorectal cancer. J Mol Diagn. 2018;20(5):664-76. https://doi. org/10.1016/j.jmoldx.2018.05.008.

68. Franczak C, Dubouis L, Gilson P, Husson M, Rouyer M, Demange J, Leroux A, Merlin JL, Harle A. Integrated routine workflow using next-generation sequencing and a fully-automated platform for the detection of KRAS, NRAS and BRAF mutations in formalin-fixed paraffin embedded samples with poor DNA quality in patients with colorectal carcinoma. PLoS ONE. 2019;14(2):e0212801. https://doi.org/10.1371/journal.pone.02128 01.

69. Cui Y, Cui X, Yang X, Zhuo Z, Du X, Xin L, Yang Z, Cheng X. Diffusion kurtosis imaging-derived histogram metrics for prediction of KRAS mutation in rectal adenocarcinoma: preliminary findings. J Magn Reson Imaging. 2019;50(3):930-9. https://doi. org/10.1002/jmri.26653.

70. Oh JE, Kim MJ, Lee J, Hur BY, Kim B, Kim DY, Baek JY, Chang HJ, Park SC, Oh JH, Cho SA, Sohn DK. Magnetic resonancebased texture analysis differentiating KRAS mutation status in rectal cancer. Cancer Res Treat. 2019. https://doi.org/10.4143/ crt.2019.050

71. Jover R, Paya A, Alenda C, Poveda MJ, Peiro G, Aranda FI, PerezMateo M. Defective mismatch-repair colorectal cancer: clinicopathologic characteristics and usefulness of immunohistochemical analysis for diagnosis. Am J Clin Pathol. 2004;122(3):389-94. https://doi.org/10.1309/V9PG-K2Y2-60VF-VULR.

72. Murphy KM, Zhang S, Geiger T, Hafez MJ, Bacher J, Berg $\mathrm{KD}$, Eshleman JR. Comparison of the microsatellite instability analysis system and the Bethesda panel for the determination of microsatellite instability in colorectal cancers. J Mol Diagn. 2006;8(3):305-11. https://doi.org/10.2353/jmoldx.2006.050092.

73. Samaison L, Grall M, Staroz F, Uguen A. Microsatellite instability diagnosis using the fully automated Idylla platform: feasibility study of an in-house rapid molecular testing ancillary to immunohistochemistry in pathology laboratories. J Clin Pathol. 2019. https://doi.org/10.1136/jclinpath-2019-205935.

74. Fusco N, Bosari S. HER2 aberrations and heterogeneity in cancers of the digestive system: implications for pathologists and gastroenterologists. World J Gastroenterol. 2016;22(35):7926-37. https ://doi.org/10.3748/wjg.v22.i35.7926.

75. Cocco E, Benhamida J, Middha S, Zehir A, Mullaney K, Shia J, Yaeger R, Zhang L, Wong D, Villafania L, Nafa K, Scaltriti M, Drilon A, Saltz L, Schram AM, Stadler ZK, Hyman DM, Benayed R, Ladanyi M, Hechtman JF. Colorectal carcinomas containing hypermethylated MLH1 promoter and wild-type
BRAF/KRAS are enriched for targetable kinase fusions. Cancer Res. 2019;79(6):1047-53. https://doi.org/10.1158/0008-5472. CAN-18-3126.

76. Marchio C, Scaltriti M, Ladanyi M, Iafrate AJ, Bibeau F, Dietel M, Hechtman JF, Troiani T, Lopez-Rios F, Douillard JY, Andre F, Reis-Filho JS. ESMO recommendations on the standard methods to detect NTRK fusions in daily practice and clinical research. Ann Oncol. 2019. https://doi.org/10.1093/annonc/mdz204.

77. Yurgelun MB, Hampel $\mathrm{H}$. Recent advances in lynch syndrome: diagnosis, treatment, and cancer prevention. Am Soc Clin Oncol Educ Book. 2018;38:101-9. https://doi.org/10.1200/ EDBK_208341.

78. Schrock AB, Ouyang C, Sandhu J, Sokol E, Jin D, Ross JS, Miller VA, Lim D, Amanam I, Chao J, Catenacci D, Cho M, Braiteh F, Klempner SJ, Ali SM, Fakih M. Tumor mutational burden is predictive of response to immune checkpoint inhibitors in MSIhigh metastatic colorectal cancer. Ann Oncol. 2019. https://doi. org/10.1093/annonc/mdz134.

79. Ou SI, Nagasaka M, Zhu VW. Liquid biopsy to identify actionable genomic alterations. Am Soc Clin Oncol Educ Book. 2018;38:978-97. https://doi.org/10.1200/EDBK_199765.

80. Cenaj O, Ligon AH, Hornick JL, Sholl LM. Detection of ERBB2 amplification by next-generation sequencing predicts HER2 expression in colorectal carcinoma. Am J Clin Pathol. 2019;152(1):97-108. https://doi.org/10.1093/ajcp/aqz031.

81. Tan K, Leong SM, Kee Z, Caramat PV, Teo J, Blanco MVM, Koay ESC, Cheong WK, Soh TI, Yong WP, Pang A. Longitudinal monitoring reveals dynamic changes in circulating tumor cells (CTCs) and CTC-associated miRNAs in response to chemotherapy in metastatic colorectal cancer patients. Cancer Lett. 2018;423:1-8. https://doi.org/10.1016/j.canlet.2018.02.039.

82. Garcia-Foncillas J, Alba E, Aranda E, Diaz-Rubio E, Lopez-Lopez $\mathrm{R}$, Tabernero J, Vivancos A. Incorporating BEAMing technology as a liquid biopsy into clinical practice for the management of colorectal cancer patients: an expert taskforce review. Ann Oncol. 2017;28(12):2943-9. https://doi.org/10.1093/annonc/mdx501.

83. Garcia-Foncillas J, Tabernero J, Elez E, Aranda E, Benavides M, Camps C, Jantus-Lewintre E, Lopez R, Muinelo-Romay L, Montagut C, Anton A, Lopez G, Diaz-Rubio E, Rojo F, Vivancos A. Prospective multicenter real-world RAS mutation comparison between OncoBEAM-based liquid biopsy and tissue analysis in metastatic colorectal cancer. Br J Cancer. 2018;119(12):1464-70. https://doi.org/10.1038/s41416-018-0293-5.

84. Sartore-Bianchi A, Loupakis F, Argiles G, Prager GW. Challenging chemoresistant metastatic colorectal cancer: therapeutic strategies from the clinic and from the laboratory. Ann Oncol. 2016;27(8):1456-66. https://doi.org/10.1093/annonc/mdw191.

85. Marcuello M, Vymetalkova V, Neves RPL, Duran-Sanchon S, Vedeld HM, Tham E, van Dalum G, Flugen G, Garcia-Barberan V, Fijneman RJ, Castells A, Vodicka P, Lind GE, Stoecklein NH, Heitzer E, Gironella M. Circulating biomarkers for early detection and clinical management of colorectal cancer. Mol Aspects Med. 2019. https://doi.org/10.1016/j.mam.2019.06.002.

86. Olmedillas-Lopez S, Garcia-Olmo DC, Garcia-Arranz M, PeiroPastor R, Aguado B, Garcia-Olmo D. Liquid biopsy by NGS: differential presence of exons (DPE) in cell-free DNA reveals different patterns in metastatic and nonmetastatic colorectal cancer. Cancer Med. 2018;7(5):1706-16. https://doi.org/10.1002/ cam4.1399.

Publisher's Note Springer Nature remains neutral with regard to jurisdictional claims in published maps and institutional affiliations. 


\section{Affiliations}

\section{P. García-Alfonso ${ }^{1}$ (1) - R. García-Carbonero ${ }^{2}$. J. García-Foncillas ${ }^{3} \cdot$ P. Pérez-Segura ${ }^{4} \cdot$ R. Salazar ${ }^{5} \cdot$ R. Vera ${ }^{6}$. S. Ramón y Cajal $^{7} \cdot$ J. Hernández-Losa ${ }^{7} \cdot$ S. Landolfi ${ }^{7} \cdot$ E. Musulén $^{8,9} \cdot$ M. Cuatrecasas $^{10} \cdot$ S. Navarro ${ }^{11}$}

R. García-Carbonero rgcarbonero@gmail.com

J. García-Foncillas jgfoncillas@gmail.com

P. Pérez-Segura perezsegura09@gmail.com

R. Salazar

ramonsalazar@iconcologia.net

R. Vera

ruth.vera.garcia@cfnavarra.es

S. Ramón y Cajal

sramon@vhebron.net

J. Hernández-Losa

javierhernandezlosa@gmail.com

S. Landolfi

slandolfi@vhebron.net

E. Musulén

eva.musulen@quironsalud.es;

emusulen@carrerasresearch.org

M. Cuatrecasas

mcuatrec@clinic.cat

S. Navarro

samuel.navarro@uv.es

1 Departament of Medical Oncology, Hospital General Universitario Gregorio Marañón, Madrid, Spain
2 Departament of Medical Oncology, Hospital Universitario 12 de Octubre, Instituto de Investigación Sanitaria Hospital 12 de Octubre (imas12), UCM, CNIO, CIBERONC, Madrid, Spain

3 Departament of Medical Oncology, Hospital Universitario Fundación Jiménez Díaz, Universidad Autónoma de Madrid, Madrid, Spain

4 Departament of Medical Oncology, Hospital Clínico Universitario San Carlos, CIBERONC, Madrid, Spain

5 Departament of Medical Oncology, ICO L'Hospitalet, Oncobell Program (IDIBELL), CIBERONC,

Hospitalet de Llobregat, Spain

6 Departament of Medical Oncology, Complejo Hospitalario de Navarra; Navarrabiomed, IDISNA, Pamplona, Spain

7 Department of Pathology, Hospital Universitario Vall D'Hebron, CIBERONC, Barcelona, Spain

8 Department of Pathology, Hospital Universitari General de Catalunya, Grupo Quirónsalud, Sant Cugat del Vallès, Spain

9 Cancer Epigenetics Group, Institut de Recerca Contra La Leucèmia Josep Carreras, Badalona, Spain

10 Department of Pathology, Hospital Clinic, CIBERehd, Barcelona, Spain

11 Department of Pathology, University of Valencia, Hospital Clínico Universitario de Valencia, CIBERONC, Valencia, Spain 